\title{
Ultrasound-guided bilateral greater occipital nerve block on headache seen after endovascular treatment of ruptured or unruptured intracranial aneurysms: A case report
}

\author{
Rüptüre olmuş ve olmamış intrakraniyal anevrizmaların endovasküler tedavisi sonrası \\ görülen başağrısında ultrason eşliğinde bilateral büyük oksipital sinir bloğu: Bir olgu sunumu
}

\author{
Rafi DOĞAN, Hüseyin Ulaş PINAR, Ömer KARACA, Fatma KARAKOÇ
}

\begin{abstract}
Summary
Headache is a common symptom in subarachnoid hemorrhage (SAH). Often, pain control is difficult and opioid use can have a complicated effect on the patient's state of consciousness. In this study of 2 cases, opioid consumption was reduced while effective pain control of headache occurring after endovascular treatment of an intracranial aneurysm was achieved using an ultrasound-guided, bilateral greater occipital nerve (GON) block. Case 1 was a 59-year-old male patient with a Glasgow Coma Scale (GCS) of 13 who was diagnosed with Fisher scale grade $3 \mathrm{SAH}$. Coiling and stenting were performed for an anterior communicating artery aneurysm. Cerebrospinal fluid drainage was provided with a lumbar spinal catheter. Case 2 was a 55-yearold male patient with a GCS of 15 who underwent coiling of a fusiform aneurysm in the left basilar artery and stenting of the stenotic region due to a basilar artery aneurysm. After the procedure, the visual analog score (VAS) of the patients was 9 and 7, respectively, and a bilateral GON block was performed with ultrasound guidance. The VAS score of both patients decreased to 3 and did not exceed 3 during follow-up in the intensive care unit, eliminating the need for additional analgesics. A bilateral GON block provided effective analgesia and significantly reduced the need for other pain relief in both cases.
\end{abstract}

Keywords: Aneurysmal subarachnoid hemorrhage; headache; occipital nerve blockade.

\begin{abstract}
Özet
SAK olgularında başağrısı sık görülen semptomdur. Çoğu zaman ağrı kontrolü güç olmakta ve opioid kullanılarak hastanın şuur durumu daha karmaşık hale gelmektedir. Çalışmada, ultrason eşliğinde bilateral büyük oksipital sinir bloğu ile intrakraniyal anevrizmaların endovasküler tedavisi (EVT) sonrası görülen başağrısının etkili kontrolünü ve opioid tüketimini azaltmayı amaçladık. Olgu1 - Fisher 3 grade SAK tanısıyla gelen, GKS: 13 olan 59 yaşında erkek hastaya, anteriör kominikan arterde anevrizma nedeniyle koilizasyon ve stent uygulaması yapıldı. Lomber spinal kateterle BOS drenajı sağlandı. Olgu 2 - Baziller arter anevrizması nedeniyle, sol baziller arterde fusiform anevrizmaya koilizasyon ve stenotik bölgeye stent uygulanan GKS: 15 olan 55 yaş erkek hasta değerlendirildi. VAS skorları sırasıyla 9-7 olan hastalara, ultrasound eşliğinde bilateral büyük oksipital sinir bloğu sağlandı. Her iki hastanın VAS skoru 3 ün altına düştü. Skor takip boyunca 3'ü aşmadı ve ek analjezik ihtiyacı olmadı. Sonuç olarak, iki olguda da bilateral oksipital sinir bloğu ile etkili analjezi sağlanmıştır ve ek analjezik ihtiyacı çok azalmıştır. Anahtar sözcükler: Anevrizmal subarahnoid kanama; başağrısı; oksipital sinir bloğu.
\end{abstract}

\section{Introduction}

Ruptured aneurysms account for approximately $80 \%$ of non-traumatic SAH. The 30-day mortality rate of aneurysmal SAH is $45 \%$ and $30 \%$ of the survivors have significant neurological problems. SAH is classically manifested with headaches.

$97 \%$ of the diagnosed patients have headache. ${ }^{[1]}$ Pain can be observed in $25-56 \%$ of the ruptured or unrup- tured aneurysms due to EVT. ${ }^{[2,3]}$ It has been reported that causes of pain include; stretching and distortion of the arteries with coiling and stenting, and inflammatory changes caused by chemicals such as glue. ${ }^{[4]}$ It has also been shown that bioactive coils and the absence of hypertension history increase the risk of headache. ${ }^{[3,5]}$ Despite the use of agents such as acetaminophen, opioids, tramadol, and gabapentin for the treatment of headache; effective pain control has

Department of Anesthesiology and Reanimation, Başkent University Faculty of Medicine, Ankara, Turkey

Submitted: 30.03.2018 Accepted after revision: 05.09.2018 Available online date: 01.10.2018

Correspondence: Dr. Rafi Doğan. Başkent Üniversitesi Tıp Fakültesi, Anesteziyoloji ve Reanimasyon Anabilim Dalı, Ankara, Turkey.

Phone: +90 - 332 - 2570606 e-mail: rafidogan@yahoo.com

(C) 2020 Turkish Society of Algology 
not been achieved and undesirable side effects of drugs have come to the forefront. These medicines may also prevent objective neurological evaluation by alteration of consciousness at different degrees.

Occipital nerve block has been shown to provide effective pain control in occipital neuralgia, cervicogenic headache, tension-type headache and migraine. ${ }^{[6-9]}$ US-guided GON block increases the efficiency and reliability of the block. ${ }^{[10]}$

In this report we will present bilateral greater occipital nerve (GON) block that is performed to two patients who underwent EVT and stenting for a ruptured and unruptured intracranial aneurysm.

\section{Case Report}

Case 1 - A 59-year-old male patient with a history of hypertension was admitted to the hospital due to unconsciousness, computerized brain tomography showed an extensive SAH (Fisher 3), which also was opened to the ventricle. Glasgow coma score (GCS) was 13 , other physical examinations were normal. Cerebral angiography showed aneurysm in anterior communicating artery. Lumbar spinal drainage catheter was inserted into the patient. After EVT, daily cerebrospinal fluid (CSF) drainage (30-40 ml/day) was performed.

Coilization and stenting were done with EVT. During the procedure, $2000 \mathrm{U}$ of fractionated heparin was administered to the patient. After the procedure, the patient was admitted to the intensive care unit (ICU). After the patient gained consciousness the pain score (VAS) was assessed as 9-10 and we decided to perform bilateral GON block. When the patient was in prone position, the external occipital protuberance (EOP) was palpated, and then the $5-12 \mathrm{~Hz}$ linear US probe was placed in the transverse position on the midline EOP and advanced to the caudal. When the $\mathrm{C} 2$ vertebra was seen, the probe was shifted laterally and the oblique capitis inferior muscle $(\mathrm{OCl})$ observed when the outer edge of the probe reached to the $\mathrm{C} 1$ transverse process level. GON was seen between $\mathrm{OCl}$ and semispinal capitis muscles and medial to occipital artery. The $25 \mathrm{G}$ spinal needle was advanced in-plane from the medial to the lateral towards the two muscle fascia. A mixture of $1 \mathrm{ml}$ of $2 \%$ lidocaine, $2.5 \mathrm{ml}$ of $0.25 \%$ bupivacaine and $3 \mathrm{mg}$ of betamethasone (total $4 \mathrm{ml}$ ) was injected into the nerve sheath. Spread between two muscles was also observed with US.

After the block the pain score was 1. The VAS was questioned 30 minutes after the block and then every 12 hours for 14 days until discharge. Oral nimodipine $360 \mathrm{mg} /$ day for vasospasm prophylaxis, and $5 \mathrm{mg}$ prasugrel and $100 \mathrm{mg}$ ASA for antiaggregant therapy were initiated. During these 14 days, if the pain score was 4 and above, paracetamol was administered $500 \mathrm{mg}$ iv 4 times a day, and tramadol $100 \mathrm{mg}$ iv was administered if the pain score did decrease. Control angiography was performed at $8^{\text {th }}$ and $10^{\text {th }}$ days because the patient became unconscious and experienced regression in motor functions. Cerebral vasospasm was observed and treated with intra arterial papaverine. After 14 days the patient was transferred to the neurology ward with minimal motor weakness on the right lower limb.

Case 2 - A 55-year-old male patient presented with left leg numbness and headache. The patient had hypertension and diabetes mellitus history. The headache was concentrated in the back of the neck, and described as constant and throbbing. GCS was 15 , minimal sensory loss in left leg was observed and other systemic examinations were normal. Computerized brain tomography revealed a basilar artery aneurysm and small infarct in the brain stem but no SAH was observed.

Under general anesthesia, left basilar artery stenting and fusiform aneurysm coiling were performed with EVT. During the procedure, $2000 \mathrm{U}$ of fractionated heparin was administered to the patient. The patient was taken to ICU after recovery from anesthesia. Because VAS score, obtained in the pain questionnaire, was 7; the patient was scheduled for bilateral USguided GON block. And performed as desribed in first case. After the block, the patient's VAS score was 2. VAS did not exceed 3 during the follow-up in ICU, so there was no need for additional analgesics. The sensory deficit of the patient resolved. Oral nimodipine $360 \mathrm{mg} /$ day for the vasospasm prophylaxis and $5 \mathrm{mg}$ prasugrel and $100 \mathrm{mg}$ ASA for antiaggregant therapy were initiated. The patient did not develop vasospasm and was transferred to the neurology ward on the $12^{\text {nd }}$ day. 


\section{Discussion}

In the presented 2 cases, effective pain control was obtained with GON block. Although Case 1 required minimal additional analgesia, it can be said that the block was effective.

There are 3 reasons for headache in aneurysmatic $\mathrm{SAH}$ which are treated by EVT. The first reason is SAH itself, the second is EVT, and the last is the drainage of the BOS with lumbar drainage in cases of extesive SAH which are opened to the ventricle. These factors can cause pain, either alone or together. In other words, it is not possible to determine which factor is responsible at any given time. The cause of headache in SAH is not fully explained, but sudden stretching of the aneurysm, local meningeal inflammation or thrombosis is implicated..$^{[5,11]}$ Pain is described as sudden, explosive and spreading to the neck. It usually takes 1-2 weeks and the pain control can be performed with only potent analgesics such as opioids and tramadol.

Sometimes very severe pain may also be resistant to continuous opioid therapy. ${ }^{[11]}$ In addition, the opioids can mask the neurological situation and the opioid antagonists are unable to remove this masking; which led researchers to search for different methods of pain control. ${ }^{[12,13]}$

In SAH cases, the activation of NMDA receptors facilitate the transmission of pain leading to hyperalgesia. ${ }^{[14]}$ By considering this fact the analgesic efficacy of magnesium, an NMDA receptor antagonist, was investigated and shown that headache was less in patients with high Mg levels. ${ }^{[15]}$ There are studies showing that $\mathrm{Mg}$ replacement therapy is effective in some headache treatments. ${ }^{[16]}$ However, information on efficacy and safety of intravenous Mg support for pain control is limited. In addition, Mg was used as neuroprotective and antivasospastic in $\mathrm{SAH}$ patients. However, additional Mg supplementation is not recommended in this regard except for keeping serum levels within normal limits. In our study, serum Mg levels in both patients were within normal limits.

Although aneurysmatic SAH patients treated with EVT are reported to have less headache, ${ }^{[17]}$ some studies reported headache related to EVT. ${ }^{[2,4,5]}$ In these patients it has been shown that causes of pain may be distortion, stretching of the vessel with coil or stent; inflammatory changes caused by chemicals such as glue. ${ }^{[4]}$ It has also been shown that bioactive coils and the absence of hypertension history increase the risk of headache. ${ }^{[2,5]}$ Evidence for the safety of tryptophan and dihydroergotamine, serotonin receptor antagonists is insufficient this type of headache. ${ }^{[4]}$

Cerebral vasospasm and cerebral ischemia are the most serious complications after $\mathrm{SAH}$, with a rate of $30-70 \% .{ }^{[18]}$ It develops most frequently between 4-14 days. ${ }^{[19]}$ It is thought that hemoglobin products in CSF are effective in the development of vasospasm. ${ }^{[20,21]}$ The effectiveness of CSF drainage to prevent vasospasm has been demonstrated by many researchers. Lumbar drainage has been shown to be more efficient than external ventricular drainage for cleaning hemoglobin products from $\mathrm{CSF}^{[22,23]} \mathrm{Al}$ though lumbar drainage can prevent vasospasm, it can also cause headache due to decreased CSF volume at the same time.

In our clinic, almost all of the ruptured or unruptured ICAs are treated with EVT. The procedure is performed under general anesthesia and the patient is followed up in the ICU. The duration of ICU stay is 10-15 days, especially due to the risk of vasospasm. Patients in ICU are also followed for headache treatment. According to the severity of headache, we use paracetamol, pregabalin, tramadol and opioids alone or in combination. We have observed many times that opioids are inadequate for pain control in severe headaches. Therefore, to increase efficacy in headache control and to move away from pregabalin, tramadol and opioids which have many side effects we decided to perform nerve blocks. We think that the most appropriate method for this purpose is the bilateral GON block.

GON block has been shown to provide effective pain control in occipital neuralgia, cervicogenic headache, tension-type headache and migraine. ${ }^{[6-9]}$ Performing the nerve block with the US guidance has increased the safety and effectiveness of the block. In a study in which the GON block was used for the treatment of occipital neuralgia and craniofacial pain syndromes, the efficacy of the block for 1 week, 1 month and 3 months was assessed and at least a 50\% reduction in the VAS score was observed. 
[10] They also emphasized that US is a safe and easily applicable imaging method. In another study, a significant reduction in pain scores over 4 weeks with GON block for cervicogenic headache and occipital neuralgia was observed and no adverse events were reported. ${ }^{[2]}$

Furthermore, the efficacy of the block also has been shown in the post-dural puncture headache. $[25,26]$ We have emphasized in our study that one of the causes of the headache might be lumbar spinal drainage. In this case, we think that headache is caused by a similar mechanism with post-dural puncture headache.

So, which mechanisms have been effective in pain control with GON block? CSF volume changing caused by dural stretch in SAH may activate the trigeminal nucleus caudalis, causing increased activity in the trigeminal and greater occipital nerves. ${ }^{[27]}$ The other theories about the genesis of pain associated with intracranial endovascular procedures include mechanical stimulation of the arterial wall by traction, stretching, and distortion from materials used (balloons, catheters, coils, glue, stent) with subsequent triggering of the trigeminovascular pathway from trigeminal C fiber stimulation. ${ }^{[28,29]}$ Additionally, GON's relation to second-order neurons of the trigeminocervical complex, which receive afferent inputs from trigeminal peripheral nerves of the face, offers insight into how GON block may contributes to relieving headaches that are more frontal than occipital in distribution. ${ }^{[30,31]}$ The analgesia obtained after GON block may be explained by the central neuromodulatory effect that causes decreased central sensitizationas a result of the temporary interruption of afferent input to the dorsal roots and trigeminal nucleus. ${ }^{[32]}$

Also in a retrospective review, adult patients with post-traumatic headaches had significant improvement in their headaches up to six months after GON block with xylocaine and methylprednisolone. ${ }^{[33]} \mathrm{Ad}$ ditionaly a study showed GON block may have a role in management of spontaneous intracranial hypotension headache. ${ }^{[27]}$

In conclusion, an efficient headache control was achieved with the bilateral GON block and the need for additional analgesic medication was severely reduced.

\section{Conflict-of-interest issues regarding the authorship or article: All authors declare no conflict interest.}

\section{Peer-rewiew: Externally peer-reviewed.}

\section{References}

1. Abraham MK, Chang WW. Subarachnoid Hemorrhage. Emerg Med Clin North Am 2016;34(4):901-16. [CrossRef]

2. Choi KS, Lee JH, Yi HJ, Chun HJ, Lee YJ, Kim DW. Incidence and risk factors of postoperative headache after endovascular coil embolization of unruptured intracranial aneurysms. Acta Neurochir (Wien) 2014;156(7):1281-7. [CrossRef]

3. Hwang G, Jeong EA, Sohn JH, Park H, Bang JS, Jin SC, et al. The characteristics and risk factors of headache development after the coil embolization of an unruptured aneurysm. AJNR Am J Neuroradiol 2012;33(9):1676-8. [CrossRef]

4. Baron EP, Moskowitz SI, Tepper SJ, Gupta R, Novak E, Hussain MS, et al. Headache following intracranial neuroendovascular procedures. Headache 2012;52(5):739-48. [CrossRef]

5. Takigawa T, Matsumaru Y, Nakai Y, Nakamura K, Hayakawa M, Tsuruta W, et al. Bioactive coils cause headache and fever after endovascular treatment of intracranial aneurysms. Headache 2012;52(2):312-21. [CrossRef]

6. Aubry S, Kastler B, Bier V, Hadjidekov V, Hussein HH, Fergane $B$. Evaluation of the effectiveness of CT-guided infiltration in the treatment of Arnold's neuralgia. Neuroradiology 2009;51(3):163-8. [CrossRef]

7. Vincent MB, Luna RA, Scandiuzzi D, Novis SA. Greater occipital nerve blockade in cervicogenic headache. Arq Neuropsiquiatr 1998;56(4):720-5. [CrossRef]

8. Young W, Cook B, Malik S, Shaw J, Oshinsky M. The first 5 minutes after greater occipital nerve block. Headache 2008;48(7):1126-8. [CrossRef]

9. Saadah HA, Taylor FB. Sustained headache syndrome associated with tender occipital nerve zones. Headache 1987;27(4):201-5. [CrossRef]

10. Zipfel J, Kastler A, Tatu L, Behr J, Kechidi R, Kastler B. Ultrasound-Guided Intermediate Site Greater Occipital Nerve Infiltration: A Technical Feasibility Study. Pain Physician 2016;19(7):E1027-34.

11. Morad AH, Tamargo RJ, Gottschalk A. The Longitudinal Course of Pain and Analgesic Therapy Following Aneurysmal Subarachnoid Hemorrhage: A Cohort Study. Headache 2016;56(10):1617-25. [CrossRef]

12. Baskin DS, Hosobuchi Y. Naloxone reversal of ischaemic neurological deficits in man. Lancet 1981;2(8241):272-5.

13. Bell BA, Miller JD, Neto NG, O'Neill P, Laughton LM. Effect of naloxone on deficits after aneurysmal subarachnoid hemorrhage. Neurosurgery 1985;16(4):498-501. [CrossRef]

14. Woolf CJ, Thompson SW. The induction and maintenance of central sensitization is dependent on N-methyl-D-aspartic acid receptor activation; implications for the treatment of post-injury pain hypersensitivity states. Pain 1991;44(3):293-9. [CrossRef]

15. Dorhout Mees SM, Bertens D, van der Worp HB, Rinkel GJ, van den Bergh WM. Magnesium and headache after aneu- 
rysmal subarachnoid haemorrhage. J Neurol Neurosurg Psychiatry 2010;81(5):490-3. [CrossRef]

16. Mauskop A, Altura BT, Cracco RQ, Altura BM. Intravenous magnesium sulfate rapidly alleviates headaches of various types. Headache 1996;36(3):154-60. [CrossRef]

17. Hong CK, Joo JY, Kim YB, Shim YS, Lim YC, Shin YS, et al. The Course of Headache in Patients With Moderate-toSevere Headache Due to Aneurysmal Subarachnoid Hemorrhage: A Retrospective Cross-Sectional Study. Headache 2015;55(7):992-9. [CrossRef]

18. Green DM, Burns JD, DeFusco CM. ICU management of aneurysmal subarachnoid hemorrhage. J Intensive Care Med 2013;28(6):341-54. [CrossRef]

19. Loch Macdonald R. Management of cerebral vasospasm. Neurosurg Rev 2006;29(3):179-93. [CrossRef]

20. Claassen J, Bernardini GL, Kreiter K, Bates J, Du YE, Copeland $\mathrm{D}$, et al. Effect of cisternal and ventricular blood on risk of delayed cerebral ischemia after subarachnoid hemorrhage: the Fisher scale revisited. Stroke 2001;32(9):201220. [CrossRef]

21. Muñoz-Guillén NM, León-López R, Túnez-Fiñana I, CanoSánchez A. From vasospasm to early brain injury: new frontiers in subarachnoid haemorrhage research. Neurologia 2013;28(5):309-16. [CrossRef]

22. Klimo P Jr, Kestle JR, MacDonald JD, Schmidt RH. Marked reduction of cerebral vasospasm with lumbar drainage of cerebrospinal fluid after subarachnoid hemorrhage. J Neurosurg 2004;100(2):215-24. [CrossRef]

23. Maeda $Y$, Shirao S, Yoneda $H$, Ishihara $H$, Shinoyama $M$, Oka $F$, et al. Comparison of lumbar drainage and external ventricular drainage for clearance of subarachnoid clots after Guglielmi detachable coil embolization for aneurysmal subarachnoid hemorrhage. Clin Neurol Neurosurg 2013;115(7):965-70. [CrossRef]

24. Pingree MJ, Sole JS, O’ Brien TG, Eldrige JS, Moeschler SM.
Clinical Efficacy of an Ultrasound-Guided Greater Occipital Nerve Block at the Level of C2. Reg Anesth Pain Med 2017;42(1):99-104. [CrossRef]

25. Akyol F, Binici O, Kuyrukluyildiz U, Karabakan G. Ultrasound-guided bilateral greater occipital nerve block for the treatment of post-dural puncture headache. Pak J Med Sci 2015;31(1):111-5. [CrossRef]

26. Uyar Türkyilmaz E, Camgöz Eryilmaz N, Aydin Güzey N, Moraloğlu Ö. Bilateral greater occipital nerve block for treatment of post-dural puncture headache after caesarean operations. Braz J Anesthesiol 2016;66(5):445-50. [CrossRef]

27. Niraj G, Critchley P, Kodivalasa M, Dorgham M. Greater Occipital Nerve Treatment in the Management of Spontaneous Intracranial Hypotension Headache: A Case Report. Headache 2017;57(6):952-5. [CrossRef]

28. Martins IP, Baeta E, Paiva T, Campos J, Gomes L. Headaches during intracranial endovascular procedures: a possible model of vascular headache. Headache 1993;33(5):227-33.

29. Beekman R, Nijssen PC, van Rooij WJ, Wijnalda D. Migraine with aura after intracranial endovascular procedures. Headache 2001;41(4):410-3. [CrossRef]

30. Bartsch T, Goadsby PJ. Increased responses in trigeminocervical nociceptive neurons to cervical input after stimulation of the dura mater. Brain 2003;126(Pt 8):1801-13. [CrossRef]

31. Busch V, Jakob W, Juergens T, Schulte-Mattler W, Kaube $H$, May A. Functional connectivity between trigeminal and occipital nerves revealed by occipital nerve blockade and nociceptive blink reflexes. Cephalalgia 2006;26(1):50-5. [CrossRef]

32. Bartsch T, Goadsby PJ. Stimulation of the greater occipital nerve induces increased central excitability of dural afferent input. Brain 2002;125(Pt 7):1496-509. [CrossRef]

33. Gawel MJ, Rothbart PJ. Occipital nerve block in the management of headache and cervical pain. Cephalalgia 1992;12(1):9-13. [CrossRef] 